Salvatierra, J., Garcia, A., and Aracena, P. 2020. "Towards a Lean Behavior Evaluation System in Latin American Construction." In: Tommelein, I.D. and Daniel, E. (eds.). Proc. $28^{\text {th }}$ Annual Conference of the International Group for Lean Construction (IGLC28), Berkeley, California, USA, doi.org/10.24928/2020/0035, online at iglc.net.

\title{
TOWARDS A LEAN BEHAVIOUR EVALUATION SYSTEM IN LATIN AMERICAN CONSTRUCTION
}

\author{
José L. Salvatierra ${ }^{1}$, Armando García ${ }^{2}$, and Pablo Aracena ${ }^{3}$
}

\begin{abstract}
Throughout its development, Lean implementation in the construction industry has been characterized only by efforts focused on the use of Last Planner System tools, without greater emphasis on the philosophical and cultural aspects associated with a paradigm shift in the industry. This research seeks to identify the main competences of professionals in charge of Lean implementations in Construction Projects from a Latin American point of view, as a basis for the development of key behavioural indicators (KBI). The results obtained correspond to the identification of the main dimensions, which in the opinion of Latin American experts make a project relate with a Lean approach in construction and a set of competences proposed for these three main preferences: collaborative planning systems, culture based on continuing improvement and developing people based on Lean thinking. In addition, as a first step towards the development of a Lean competence management system in construction, a model for assessing the level of expertise of a professional in charge of these dimensions is proposed, by separating the performances identified in one-dimensional behaviours and applying a compliance scale.
\end{abstract}

\section{KEYWORDS}

Lean Construction, Competences, Culture, Behaviour, Key Behaviour Indicators

\section{INTRODUCTION}

Over the last decade, Lean Construction philosophy has become widespread in Latin American and worldwide projects. Its implementation can be observed mostly through the application of tools that follow its principles, such as Last Planner System (Picchi and Granja, 2004; Salvatierra, Funk, and Alarcón, 2016). However, integrating the management philosophy, methodology and culture that support this new system into companies is a difficult challenge (Zuo and Zillante, 2005). So far, in order to measure the effectiveness of its application, quantitative indicators of key processes such as the Key Performance Indicators (KPI) (España, Tsao, and Hauser, 2012) have been used, leaving aside cultural and organizational problems that arise when implementing this philosophy. Improving adaptation to these new systems involves changing the

1 Researcher and Construction Area Coordinator, Department of Civil Engineering, University of Chile, Av. Blanco Encalada 2002, Santiago, Chile, jsalvatierra@ing.uchile.cl, orcid.org/0000-0002-1065$\underline{3051}$

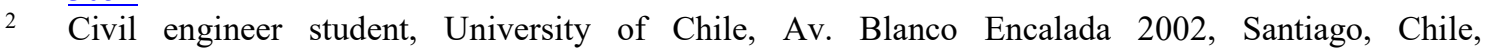
armando.garcia@ug.uchile.cl, orcid.org/0000-0003-4050-7829

3 Change Management Consultant, Leaninn, Perez Valenzuela 1635, Piso 10, Providencia, Santiago, Chile, pablo@lean-inn.com, orcid.org/0000-0003-1033-8585 
management practices of professionals in charge of these new dimensions (Pavez and Alarcon, 2007).

The purpose of this study is to advance in the development of a Lean competence management system in construction with the objective of establishing future key behaviour assessment indicators (KBIs) that allow evaluation of cultural aspects in the transformation process. For this purpose, updating, validating and complementing professional competences found in previous studies will be carried out, in association with a Lean professional who is in charge of its implementation in Latin American projects. With this, a deeper development of competences is proposed through the description of behaviours associated with these competences. Graduating their fulfillment may lead to create an evaluation tool that allows identifying and measuring a professional's level of ability or expertise regarding these, so as to help in the analysis of their performance in projects managed under a Lean approach beyond the implementation of Last Planner System.

\section{PROFESSIONAL COMPETENCE}

In order to identify an individual's characteristics that may predict his/her adequate performance in a job position, the Human Resources area has developed a series of theories and models to define and explain the competences this individual must exhibit so as to meet the requirements of a certain level of position, whether generic or specific to a particular industry and/or organization. A professional competence can be defined as a person's underlying characteristics, which are related to the successful performance of a job (Boyatzis, 1982). As the deepest development level, a description of the associated behaviours can be outlined; these are the final and tangible expression of the competences' internal characteristics, and they can be defined as the way people proceed in the face of stimuli in relation to their surroundings (Alles, 2006).

When a position or professional is required to be evaluated, measured or analysed, competence dictionaries are consulted. These establish sufficiency degrees by describing behaviours related to each level (Alles, 2006), but usually fall into broad and subjective definitions that make difficult their evaluation process. Investigating the objective description and graduation of these behaviours represents a job opportunity not yet explored in the construction area, and its development can lead to the application of a management system based on competences in construction.

\section{METHODOLOGY}

The research was carried out through the completion of 4 main stages. As a first step, in a preparatory phase an attempt was made to delimit the problem to be studied, and the necessary theoretical framework was developed to address its solution. For this purpose, the context in which Lean Construction is framed at a Latin American level, and the concept of Professional Competence were developed.

Once this process was completed, a field work phase was followed in which the first action sought to identify the main dimensions that make up a Lean project, in order to adequately conduct the areas in which the competences that a professional must possess would develop. This stage was carried out thanks to the consultation of Latin American experts who have applied Lean throughout their careers, through the construction of an online questionnaire whose details are explained in their respective section. 
With the obtained results, a literary review was carried out with the aim of building a set of professional competences for each dimension, and thanks to the application of online questionnaires and interviews with experts on charge of said dimensions in projects that work under a Lean approach, new behaviours not identified in previous studies are validated, complemented and/or recognized.

In an analytical phase a competency management model is proposed, which in the future could allow evaluating the level of compliance of a professional in the rescued competences, and thus determine the degree of expertise achieved in the domain of the identified dimensions. Finally, in the Informative Phase the work done is analysed and guidelines for its future development are suggested

Figure 1 summarizes the research methodology process phase by phase.

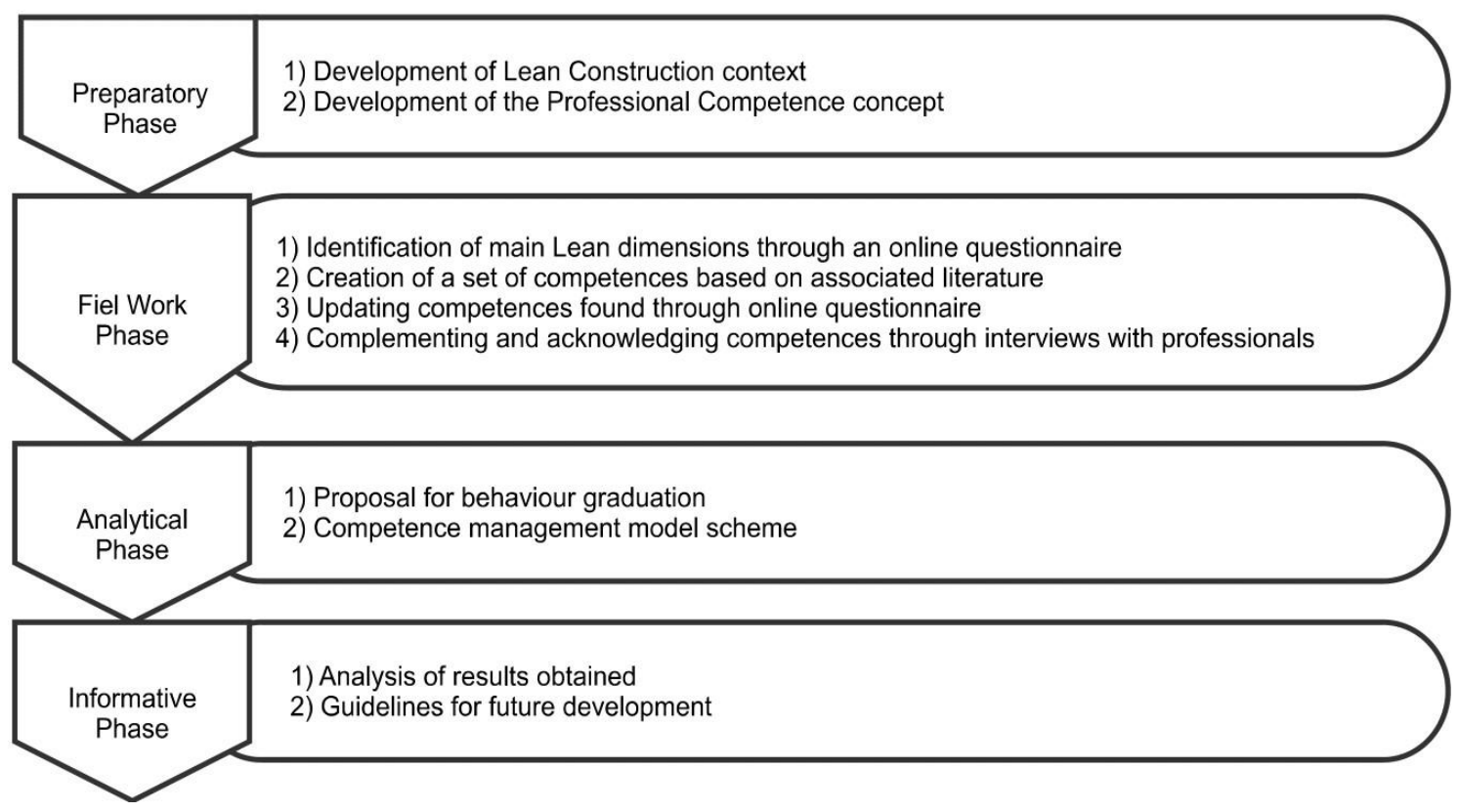

Figure 1: Work Methodology Scheme

\section{STUDY SAMPLE}

A total of 72 Latin American experts in charge of the implementation of Lean Construction in building projects were consulted to carry out this research. All of them participated by answering two online questionnaires developed to build the proposed set of competences, and a subset of 13 was interviewed virtually to inquire more deeply about the obtained results. The sample of experts consulted in questionnaires is based on ease of access, so it does not respond to probabilistic and random criteria. Regarding sample size in the case of experts interviewed, it is relevant to clarify that it was determined based on the principle of data saturation, that is to say, up to a point where conducting a new interview does not provide new information. Interviews were carried out following the selection pattern defined by chain sampling, which is based on the notion of social network, and it consists of progressively expanding the number of informants thanks to the presentation made by the subjects already included in field work. This allows minimizing possible asymmetries and coercions of an interview, thus facilitating the establishment of a trust relationship with the interviewee.

The distribution by country and characterization of Lean experts consulted is shown in Table 1. 
Table 1: Characterization of Lean experts consulted

\begin{tabular}{ccclc}
\hline Country & $\begin{array}{c}\text { Experts } \\
\text { Questionnaire }\end{array}$ & $\begin{array}{c}\text { Experts } \\
\text { Interviewed }\end{array}$ & \multicolumn{1}{c}{$\begin{array}{c}\text { Experts Interviewed } \\
\text { Positions }\end{array}$} & $\begin{array}{c}\text { Years of } \\
\text { Experience } \\
\text { in Lean }\end{array}$ \\
\hline Chile & 32 & 3 & $\begin{array}{l}\text { Operational Excellence Manager; Head } \\
\text { of Lean Implementation; Deputy } \\
\text { Manager of Quality and Innovation }\end{array}$ & $8 ; 10 ; 13$ \\
$\begin{array}{c}\text { Colombi } \\
\text { a }\end{array}$ & 13 & 3 & $\begin{array}{l}\text { Planning and Coordination Director; } \\
\text { Lean Construction Coordinator; Lean } \\
\text { Manager }\end{array}$ & $8 ; 6 ; 2$ \\
Peru & 10 & 4 & $\begin{array}{l}\text { Construction Supervisor; Technical } \\
\text { Manager; General Manager; CEO }\end{array}$ & $8 ; 11 ; 12 ;$ \\
Argentin & 4 & 1 & Planning Manager & 14 \\
a & 5 & - & & - \\
Brazil & 3 & 2 & $\begin{array}{l}\text { Project Director; Independent } \\
\text { Consultant }\end{array}$ \\
$\begin{array}{c}\text { Bolivia } \\
\text { Mexico }\end{array}$ & 4 & - & & - \\
Ecuador & 1 & - & & - \\
\hline Total & $\mathbf{7 2}$ & 13 & & - \\
\hline
\end{tabular}

\section{Main Dimensions}

The first step to identify the professional competences that a person in charge of the implementation of Lean in construction projects must possess, is to determine which are the dimensions of this new philosophy in which they must be framed. Lean has been put into practice through a series of action areas throughout its development, and it is necessary to select among them the most relevant for its application.

In the preparatory phase, a review of the associated literature was carried out, analyzing the different aspects that must be considered for a correct execution of Lean in the construction industry (Erol, Dikmen, and Birgonul, 2017; Salunkhe, 2018). From this work, a list of 12 main dimensions is developed, which according to bibliographic research a project must have to be considered Lean.

Once identified, the next step was to determine which of them are key to the application of this philosophy in construction. To accomplish this, Latin American experts were asked through an online questionnaire about the dimensions deemed as essential when considering a project managed under a Lean approach, determining the relative importance of each one. Results are shown in Table 2. 
Table 2: Main Dimensions Identified by Experts

\begin{tabular}{cl}
\hline Level of importance & \\
\hline High Level & Culture based on continuous improvement \\
$75 \%-100 \%$ & People development based on Lean thinking \\
& Collaborative planning systems \\
\hline & Visual management of key project indicators \\
& Subcontract and supply chain involvement \\
Intermediate Level & Productivity management \\
$50 \%-75 \%$ & Tool application / implementation \\
& Information flow management \\
& Change management model \\
& Organizational structure tending to horizontality \\
& Quality management \\
Low Level & Use of technological tools supporting project productivity and \\
& information flow, such as: planning and BIM software \\
\hline
\end{tabular}

\section{Proposed CoMpeTences}

With the main dimensions obtained, the professional competences associated with them were identified through a literary review of previous studies that address their development. Due to the extension of the work to be carried out, during this research the main dimensions indicated with a high level of importance were covered: people development based on Lean thinking (Alarcon, y otros, 2017; Pavez and Alarcon, 2008), a Culture based on continuous improvement (Bessant, Caffyn, and Gallagher, 2001), and Collaborative Planning Systems (Fauchier and Alves, 2013)

To update and verify the results found in Latin American reality, an online questionnaire was prepared for professionals of the region who have applied Lean throughout their careers. In it, it was asked to rate the importance and adequacy of them on a scale of appreciation. The proposed set of competencies was mostly approved by the experts, and none of them was indicated as inappropriate under a Latin American perspective.

In this way, Tables 3,4 , and 5 show the final set of competencies to be proposed for each main dimension, with their associated behaviours and the most representative quote from the interviews conducted that reflects their presence, if it was identified

Table 3: Competences. People Development based on Lean thinking

\begin{tabular}{cll}
\hline Competence & \multicolumn{1}{c}{ Behaviour } & \multicolumn{1}{c}{ Quotation } \\
\hline Leadership & $\begin{array}{l}\text { Demonstrating commitment to } \\
\text { the Lean principles they are } \\
\text { trying to teach through concrete } \\
\text { actions; providing examples of } \\
\text { how these teachings are } \\
\text { materializing during meetings. }\end{array}$ & $\begin{array}{l}\text { "People who are not consistent with what they } \\
\text { convey in a meeting finally fail to implement their } \\
\text { ideas. A leader can give a talk, go to a seminar, } \\
\text { lecture and disseminate, but if later on you don't get } \\
\text { to do it, it loses all validity. You should not have a } \\
\text { glass roof; if you're really convinced, you have to } \\
\text { prove it with facts in every way" }\end{array}$ \\
\cline { 2 - 3 } & $\begin{array}{l}\text { Promoting teamwork by } \\
\text { highlighting the concept of }\end{array}$ & $\begin{array}{l}\text { "It's all about breaking verticality and promoting } \\
\text { horizontality; it shouldn't depend on anyone's will and } \\
\text { everyone should always be given participation... }\end{array}$ \\
\hline
\end{tabular}




\begin{tabular}{|c|c|c|}
\hline & $\begin{array}{l}\text { value chain and the definition of } \\
\text { shared achievements. }\end{array}$ & $\begin{array}{l}\text { What is done and commented is that the protagonist } \\
\text { is the project itself and not someone in particular" }\end{array}$ \\
\hline & $\begin{array}{l}\text { Encouraging and promoting } \\
\text { relationships of respect and } \\
\text { empathy among colleagues. }\end{array}$ & $\begin{array}{l}\text { "The key is that people must respect each other; } \\
\text { without that, you get nowhere" }\end{array}$ \\
\hline \multirow[t]{3}{*}{$\begin{array}{c}\text { Strategic } \\
\text { Perspective }\end{array}$} & $\begin{array}{l}\text { Promoting changes based on } \\
\text { the company's strategy. } \\
\text { Decisions and behaviours are } \\
\text { always based on it, } \\
\text { understanding that decisions } \\
\text { can affect it. Supporting these } \\
\text { changes with figures and } \\
\text { objective data. }\end{array}$ & $\begin{array}{l}\text { "At a company level, it is key to support decisions } \\
\text { with figures and objective results. On site, practices } \\
\text { are encouraged by showing what is being lost, } \\
\text { showing money wasted on materials with figures" }\end{array}$ \\
\hline & $\begin{array}{l}\text { Communicating good results } \\
\text { obtained and connecting them } \\
\text { with the implementation of Lean } \\
\text { in the organization. }\end{array}$ & $\begin{array}{l}\text { "First it should be useful; it should deliver results and } \\
\text { they must be communicated. When something } \\
\text { works, it is sustained; Lean has to be useful to keep } \\
\text { it in the company" }\end{array}$ \\
\hline & $\begin{array}{l}\text { Anticipating internal and } \\
\text { external challenges to adapt } \\
\text { their strategies to projects, } \\
\text { disseminating changes so that } \\
\text { the rest of the organization } \\
\text { learns from them. }\end{array}$ & No specific quote recognized \\
\hline \multirow[t]{4}{*}{$\begin{array}{l}\text { Communicativ } \\
\text { e- } \\
\text { Disseminating } \\
\text { Capacity }\end{array}$} & $\begin{array}{l}\text { Encouraging everyone involved } \\
\text { in the decision-making process } \\
\text { to participate and give opinions. }\end{array}$ & $\begin{array}{l}\text { "They must be in charge, but they must not be the } \\
\text { only ones; every so often you have to involve people } \\
\text { in the team, and if you need to moderate a meeting } \\
\text { or any of the members of the meeting invite them to } \\
\text { be wrong, just do it" }\end{array}$ \\
\hline & $\begin{array}{l}\text { Building relationships of trust } \\
\text { with people and connect with } \\
\text { them by showing interest, } \\
\text { asking about everyday issues } \\
\text { and finding out how they feel. }\end{array}$ & $\begin{array}{l}\text { "I used to ask them a few simple questions: how did } \\
\text { you sleep, is your food tasty?... Those day-to-day } \\
\text { details build up a relationship and end up being } \\
\text { positive, because showing interest is not a benefit } \\
\text { just for the company, but not everyone!" }\end{array}$ \\
\hline & $\begin{array}{l}\text { Explaining the theory in a } \\
\text { didactic way and applying it to } \\
\text { people's daily work, by } \\
\text { spreading Lean culture through } \\
\text { talks. }\end{array}$ & $\begin{array}{l}\text { "And we make a series of drawings, videos, little } \\
\text { figures, videos in the work sites... for people to be } \\
\text { absorbing these kinds of issues all the time, so that a } \\
\text { culture is generated" }\end{array}$ \\
\hline & $\begin{array}{l}\text { Maintaining a systematic and } \\
\text { constant application of culture } \\
\text { inside the organization }\end{array}$ & $\begin{array}{l}\text { "Second, the systematic application, to be } \\
\text { measuring, to be watching. Because the tendency, } \\
\text { especially when the work reaches a peak is to leave } \\
\text { everything lying down; that is the worst symptom. } \\
\text { Leaving it alone in the hands of the work team is } \\
\text { risky" }\end{array}$ \\
\hline \multirow[t]{3}{*}{$\begin{array}{l}\text { Conflict } \\
\text { Resolution }\end{array}$} & $\begin{array}{l}\text { Finding the cause of the } \\
\text { problem and taking action, } \\
\text { making sure it does not happen } \\
\text { again. }\end{array}$ & $\begin{array}{l}\text { "The idea is to constantly analyze and correct, } \\
\text { reaching the root cause to correct the process and } \\
\text { not the people" }\end{array}$ \\
\hline & $\begin{array}{l}\text { Making decisions in a timely } \\
\text { manner, granting clear } \\
\text { guidelines for the solution and } \\
\text { making sure that everyone } \\
\text { understood. }\end{array}$ & No specific quote recognized \\
\hline & $\begin{array}{l}\text { Delegating problematic issues } \\
\text { to superiors when appropriate, } \\
\text { only when it cannot be solved, } \\
\text { and presenting alternative } \\
\text { solutions }\end{array}$ & No specific quote recognized \\
\hline
\end{tabular}


Table 4: Competences. Collaborative Planning Systems

\begin{tabular}{|c|c|c|}
\hline Competence & Behaviour & Quotation \\
\hline \multirow[t]{3}{*}{ Leadership } & $\begin{array}{l}\text { Establishing clear and well- } \\
\text { defined commitments, defining } \\
\text { scopes and execution times. }\end{array}$ & $\begin{array}{l}\text { "What is up to each one to do has to be very well } \\
\text { delimited and clear because otherwise many } \\
\text { problems will arise" }\end{array}$ \\
\hline & $\begin{array}{l}\text { Worrying about highlighting } \\
\text { what people did well and not } \\
\text { just pointing out mistakes. }\end{array}$ & $\begin{array}{l}\text { "As for opinions, it is said that they must be in a } \\
\text { sequence of one negative every three positive ones; } \\
\text { otherwise, the team is charged negatively. Then, I } \\
\text { can't only point out the errors but also show that they } \\
\text { did well" }\end{array}$ \\
\hline & $\begin{array}{l}\text { Being able to discern when the } \\
\text { work team must be demanded } \\
\text { for achievements and when } \\
\text { they have to sit down with them } \\
\text { to discuss and analyse the } \\
\text { problem. }\end{array}$ & $\begin{array}{l}\text { "When I experienced a managerial leader, many } \\
\text { people resigned because of his character and } \\
\text { temperament, but it was a work that was progressing } \\
\text { well; I also experienced a more democratic leader, } \\
\text { and this made people to be not so well committed. } \\
\text { You have to handle that, put pressure when you } \\
\text { have to and release when appropriate" }\end{array}$ \\
\hline \multirow[t]{3}{*}{$\begin{array}{c}\text { Strategic } \\
\text { Perspective }\end{array}$} & $\begin{array}{l}\text { Establishing a link between } \\
\text { organisational results and the } \\
\text { correct implementation of LPS }\end{array}$ & $\begin{array}{l}\text { "The only way to convince them is to show them that } \\
\text { the tool works... we show them results; we highlight } \\
\text { them in the company magazine; we generate } \\
\text { balances; we always show that the result of the work } \\
\text { is associated with the implementation of LPS" }\end{array}$ \\
\hline & $\begin{array}{l}\text { Setting clear production } \\
\text { objectives and previously } \\
\text { defining the metrics used to } \\
\text { control progress. }\end{array}$ & $\begin{array}{l}\text { "They realised that if deadlines were measured and } \\
\text { managed, they could use time on other activities. } \\
\text { They always got the idea that if they advanced faster, } \\
\text { it would be better for them and for everyone" }\end{array}$ \\
\hline & $\begin{array}{l}\text { Planning short-term goals since } \\
\text { their compliance leads to the } \\
\text { fulfillment of long-term goals. }\end{array}$ & No specific quote recognized \\
\hline \multirow[t]{5}{*}{$\begin{array}{c}\text { Teaching } \\
\text { Ability }\end{array}$} & $\begin{array}{l}\text { Ensuring systematic and } \\
\text { constant execution of planning } \\
\text { meetings. }\end{array}$ & $\begin{array}{l}\text { "You have to establish work routines for people; if } \\
\text { you don't, you will always be stuck and you won't } \\
\text { move forward. A routine consists of work guidelines, } \\
\text { a meeting routine" }\end{array}$ \\
\hline & $\begin{array}{l}\text { Building a collaborative } \\
\text { environment where planning is } \\
\text { carried out by all participants } \\
\text { involved. }\end{array}$ & $\begin{array}{l}\text { "Then the culture is generated, based on a } \\
\text { requirement to ensure that all participants are there } \\
\text { and plan" }\end{array}$ \\
\hline & $\begin{array}{l}\text { Promoting systematic thinking } \\
\text { and methodological analysis of } \\
\text { the causes of problems. }\end{array}$ & No specific quote recognized \\
\hline & $\begin{array}{l}\text { Highlighting the importance of } \\
\text { identifying customer value in } \\
\text { decision making. }\end{array}$ & $\begin{array}{l}\text { "That is a very powerful example of collaborative } \\
\text { planning, but always led by the client's needs. That is } \\
\text { the big difference; the customer is always right!" }\end{array}$ \\
\hline & $\begin{array}{l}\text { Allocating a specific workspace } \\
\text { for collaborative planning } \\
\text { activities where system tools } \\
\text { can be used. }\end{array}$ & $\begin{array}{l}\text { "Well, what should be done is considering an office } \\
\text { as everybody's office; everyone can use it to plan. } \\
\text { Nobody has a key; it is open and good integration of } \\
\text { people is generated" }\end{array}$ \\
\hline \multirow[t]{3}{*}{$\begin{array}{l}\text { Communicativ } \\
\text { e- } \\
\text { Disseminating } \\
\text { Capacity }\end{array}$} & $\begin{array}{l}\text { Following an argumentative } \\
\text { approach when disseminating } \\
\text { information or decisions, and } \\
\text { ensuring that people } \\
\text { understand why, by highlighting } \\
\text { their contributions to the } \\
\text { decision making process. }\end{array}$ & $\begin{array}{l}\text { "Yes, what we do is working with the planning tool, } \\
\text { but associated with this we hold a series of trainings } \\
\text { that over time disseminate this idea and explain why } \\
\text { we do things. Understanding why certain policies are } \\
\text { established, or how they were established as a whole } \\
\text { and their influence" }\end{array}$ \\
\hline & $\begin{array}{l}\text { Promoting open participation in } \\
\text { meetings and transparency } \\
\text { when communicating problems. }\end{array}$ & $\begin{array}{l}\text { "And there must also be a real collaborative } \\
\text { environment; if the organization doesn't have that, } \\
\text { the process is more difficult, for things to be said, for } \\
\text { transparency, etc." }\end{array}$ \\
\hline & $\begin{array}{l}\text { Performing dynamic and } \\
\text { teamwork activities to }\end{array}$ & $\begin{array}{l}\text { "The first thing I do is organising teamwork dynamic } \\
\text { activities; during a whole morning we present Team }\end{array}$ \\
\hline
\end{tabular}


encourage communication among meeting participants
Building challenges in which people who did not talk much to each other form teams opposed to other people, and that breaks the ice with people who didn't talk to each other. A collaborative environment was created"

Table 5: Competences. Culture based on Continuous Improvement

\begin{tabular}{|c|c|c|}
\hline Competence & Behaviour & Quotation \\
\hline \multirow[t]{4}{*}{ Leadership } & $\begin{array}{l}\text { Supporting the creation of } \\
\text { continuous improvement } \\
\text { projects avoiding punishing } \\
\text { eventual errors after their } \\
\text { implementation, motivating } \\
\text { employees to learn from them. }\end{array}$ & $\begin{array}{l}\text { "Yes, we have been unsuccessful... This can be } \\
\text { considered as improvement actions; we do not see } \\
\text { this as mistakes even when it costs us money } \\
\text { because otherwise people would be afraid to } \\
\text { propose" }\end{array}$ \\
\hline & $\begin{array}{l}\text { Recognising, highlighting and } \\
\text { appreciating, the contribution of } \\
\text { employees to the process of } \\
\text { continuous improvement, not } \\
\text { necessarily through monetary } \\
\text { reward. }\end{array}$ & $\begin{array}{l}\text { "A series of acknowledgements are offered so we } \\
\text { invite them to all the work sites, and the year's } \\
\text { improvements are presented; it is revealed that they } \\
\text { have managed to get savings; first places are } \\
\text { awarded prizes; they are given lunch tickets, days } \\
\text { off, etc. " }\end{array}$ \\
\hline & $\begin{array}{l}\text { Being actively involved and } \\
\text { participating in the processes of } \\
\text { continuous improvement, } \\
\text { leading by example. }\end{array}$ & $\begin{array}{l}\text { "The Lean topic must be discussed by workers and } \\
\text { those above. If you work on site but managers and } \\
\text { executives do not empower or support people, none } \\
\text { of that works. If you let people do it on their own, it } \\
\text { doesn't work. You have to supervise them; } \\
\text { otherwise, they won't do it." }\end{array}$ \\
\hline & $\begin{array}{l}\text { Being open and receptive to the } \\
\text { improvement ideas proposed; } \\
\text { showing interest and always } \\
\text { giving people time to explain } \\
\text { themselves. }\end{array}$ & $\begin{array}{l}\text { "When there is improvement, the Lean manager } \\
\text { meets with the people who proposed it and asks } \\
\text { them why they are doing it; they reply "I thought so", } \\
\text { and the manager replies by saying that they will } \\
\text { study it with this methodology and then explain it to } \\
\text { them. They internalise that knowledge and then } \\
\text { share it with others. That's the incentive; at the } \\
\text { beginning we received improvements just as they } \\
\text { arrived " }\end{array}$ \\
\hline \multirow[t]{3}{*}{$\begin{array}{c}\text { Strategic } \\
\text { Perspective }\end{array}$} & $\begin{array}{l}\text { Using the objectives and } \\
\text { organizational goals as a basis } \\
\text { for applying continuous } \\
\text { improvement, and prioritising } \\
\text { improvements that are } \\
\text { understandable by all entities of } \\
\text { the organization. }\end{array}$ & $\begin{array}{l}\text { "We have a pyramid hierarchy involving the entire } \\
\text { company, but each process has a distinct } \\
\text { improvement level according to the area. We work on } \\
\text { improvement as a failure or an opportunity as such. } \\
\text { We try to establish our main focus every year along } \\
\text { with the management" }\end{array}$ \\
\hline & $\begin{array}{l}\text { The impact each Continuous } \\
\text { Improvement cycle has on the } \\
\text { organizational results and the } \\
\text { company's objectives is } \\
\text { analysed, allowing progress } \\
\text { quantifying and supporting its } \\
\text { implementation. }\end{array}$ & $\begin{array}{l}\text { "Establishing a continuous improvement must be } \\
\text { accompanied by a global indicator; modifying a } \\
\text { process must influence the global flow and that must } \\
\text { be shown... nobody tells you: "Hey! We measure } \\
\text { these indicators at the beginning and at the end, and } \\
\text { this is how we improve"” }\end{array}$ \\
\hline & $\begin{array}{l}\text { Establishing continuous } \\
\text { improvement as a main part of } \\
\text { the workers' personal and team } \\
\text { work; they do not consider it as } \\
\text { a parallel activity. }\end{array}$ & $\begin{array}{l}\text { "When the talk ends they are shown a video of what } \\
\text { is being done in other work sites; they are told that } \\
\text { they can also do it here, let's implement it, and } \\
\text { whoever has an idea about that improvement is } \\
\text { welcome to tell us; it is a day-to-day task" }\end{array}$ \\
\hline \multirow[t]{2}{*}{$\begin{array}{l}\text { Teaching } \\
\text { Ability }\end{array}$} & $\begin{array}{l}\text { Promoting belief in continuous } \\
\text { improvement inside the } \\
\text { organization, highlighting the } \\
\text { value of taking small steps and } \\
\text { everyone contributing to the } \\
\text { improvement process. }\end{array}$ & $\begin{array}{l}\text { "Here people are taught and are made part of the } \\
\text { process. Then, afterwards they can say that they } \\
\text { performed VSM, an analysis of causes, that they } \\
\text { calculated the process times, etc. Then, later people } \\
\text { will say: 'if someone was able, why shouldn't I be } \\
\text { able'. But because we sat with them" }\end{array}$ \\
\hline & $\begin{array}{l}\text { Implementing a formal cycle of } \\
\text { problems and solutions }\end{array}$ & No specific quote recognized \\
\hline
\end{tabular}




\begin{tabular}{|c|c|c|}
\hline & \multicolumn{2}{|l|}{$\begin{array}{l}\text { identification in which the } \\
\text { participants of the organization } \\
\text { get involved. }\end{array}$} \\
\hline & $\begin{array}{l}\text { Integrating the people who } \\
\text { propose ideas for continuous } \\
\text { improvement into the analysis } \\
\text { and application of Lean tools } \\
\text { process, by making them part } \\
\text { of the work and teaching them } \\
\text { how to proceed so that they can } \\
\text { later disseminate among peers. }\end{array}$ & $\begin{array}{l}\text { "What we want is people to analyze it, to perform a } \\
\text { VSM } 5 \text { Why and see that it is something that can be } \\
\text { replicated in other work sites... they may not } \\
\text { understand everything, but they participate in } \\
\text { generating the presentation, the cost issue, photos, } \\
\text { etc. They take it very well; they see it as an } \\
\text { acknowledgement }\end{array}$ \\
\hline \multirow[t]{3}{*}{$\begin{array}{l}\text { Communicativ } \\
\text { e- } \\
\text { Disseminating } \\
\text { Capacity }\end{array}$} & $\begin{array}{l}\text { Using the techniques and tools } \\
\text { that best adapt to work team in } \\
\text { order to publish and } \\
\text { disseminating continuous } \\
\text { improvement processes, with } \\
\text { flexibility (e.g., Format A3) }\end{array}$ & $\begin{array}{l}\text { "In general, I don't agree with the rigidity of these } \\
\text { processes, in the sense that I am not very keen on } \\
\text { having to force everyone to use A3, because there } \\
\text { may be people who use other methods that are as } \\
\text { valid and powerful, and they are easier for them. And } \\
\text { that depends a lot on the work teams in the projects" }\end{array}$ \\
\hline & $\begin{array}{l}\text { Defining continuous } \\
\text { improvement projects clearly } \\
\text { and within a given period of } \\
\text { application, always } \\
\text { communicating their results and } \\
\text { their feasible implementation. }\end{array}$ & $\begin{array}{l}\text { "That idea has to be supported by the technical area, } \\
\text { it is endorsed, it is planned and we also award } \\
\text { prizes: the best improvement of the month goes to } \\
\text { such work site, such worker, etc." }\end{array}$ \\
\hline & $\begin{array}{l}\text { Promoting the participation of } \\
\text { all the people in the } \\
\text { organization involved in the } \\
\text { process of continuous } \\
\text { improvement. }\end{array}$ & $\begin{array}{l}\text { "We have quality facilitators on site; they train the } \\
\text { team on site, it is key that people build them... You } \\
\text { don't get anything done on your own, you have to } \\
\text { build it with the process owner." }\end{array}$ \\
\hline
\end{tabular}

\section{MODEL PROPOSITION}

If the set of professional competencies proposed for the main dimensions is analyzed, it should be noted that it reflects the same deficiencies identified in the characteristics of a competence. The description of the behaviours associated with each competence falls into broad sentences made up of a large number of factors to consider, making it difficult to eventually evaluate them.

To solve this problem, it is proposed that future developments could be based on building more complex competency models, disaggregating the identified behaviours into one-dimensional factors that do not encourage subjectivity, and allow determining their level of achievement on a numerical scale. These one-dimensional factors should be simple and unique actions that can be judged by whether or not they are performed, in order to facilitate the evaluation process.

As an example, Table 6 shows the disaggregation of one of the behaviours associated with leadership competence, in the Continuous Improvement dimension. 
Table 6: Example of the disaggregation and achievement scale of one of the behaviours associated with leadership competence, in the Continuous Improvement dimension

\begin{tabular}{|c|c|c|c|c|c|c|c|}
\hline \multirow[b]{2}{*}{ Competence } & \multirow[b]{2}{*}{ Behaviour } & \multirow[b]{2}{*}{$\begin{array}{c}\text { One-dimensional } \\
\text { factor }\end{array}$} & \multicolumn{5}{|c|}{ Scale } \\
\hline & & & $\begin{array}{c}1 \\
\text { Never }\end{array}$ & $\begin{array}{c}2 \\
\text { Sometimes }\end{array}$ & $\begin{array}{c}3 \\
\text { Yes }\end{array}$ & $\begin{array}{c}4 \\
\text { Often }\end{array}$ & $\begin{array}{c}5 \\
\text { Always }\end{array}$ \\
\hline \multirow{4}{*}{ Leadership } & \multirow{4}{*}{$\begin{array}{l}\text { Supporting the } \\
\text { creation of } \\
\text { continuous } \\
\text { improvement } \\
\text { projects avoiding } \\
\text { punishing eventual } \\
\text { errors after their } \\
\text { implementation, } \\
\text { motivating } \\
\text { employees to learn } \\
\text { from them }\end{array}$} & $\begin{array}{l}\text { Supporting the creation of } \\
\text { continuous improvement } \\
\text { projects. }\end{array}$ & & & & & $x$ \\
\hline & & $\begin{array}{l}\text { Tolerating errors after } \\
\text { project implementation. }\end{array}$ & & & & $x$ & \\
\hline & & $\begin{array}{l}\text { Avoiding punishing failure } \\
\text { after implementation errors } \\
\text { arise. }\end{array}$ & & & $x$ & & \\
\hline & & $\begin{array}{l}\text { Motivating people to see } \\
\text { failure as learning } \\
\text { opportunities. }\end{array}$ & & & & $x$ & \\
\hline
\end{tabular}

By applying this graduation to all the proposed competences, the next step is to propose a model for evaluating the level of expertise of a professional in charge of the main dimensions identified.

The proposed model consists of taking advantage of the possibility of determining the degree of mastery of a person in a given competence, and thus expanding that result to the general domain of the dimension to be analyzed. As outlined in Figure 3, the objective is to successively determine the percentage of compliance of the professional to be evaluated, starting by averaging the level obtained from the one-dimensional factors that make up a behaviour, until ending by averaging the percentage of compliance with the main dimensions identified.

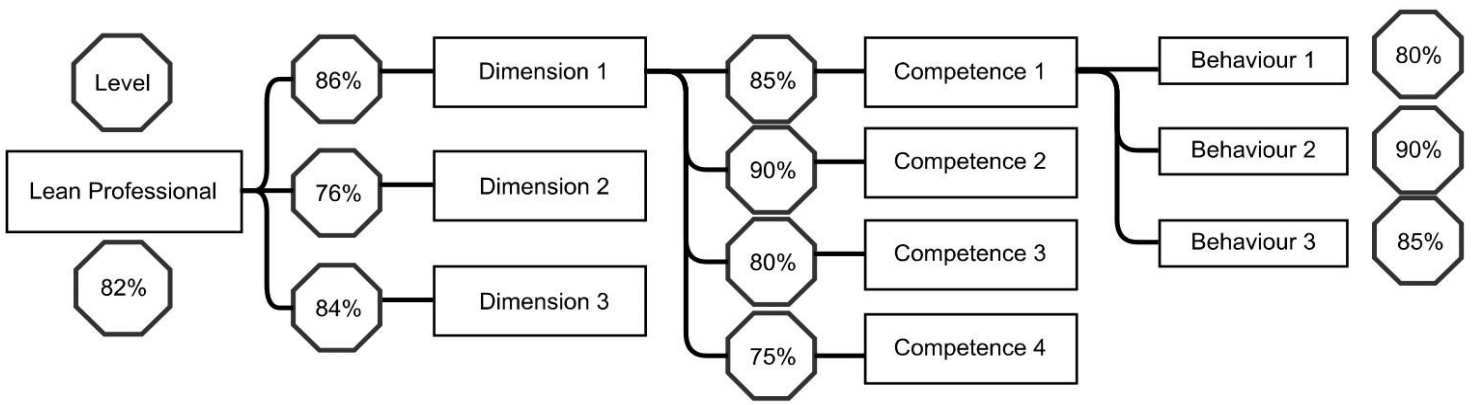

Figure 3: Evaluation Model for a Lean Professional

For this, Formula 1 averages the scores obtained in the one-dimensional factors associated with a behaviour, in order to obtain the degree of mastery of the person in each of these. Once this step has been carried out, behaviours must be averaged for each competence, and then for each dimension, obtaining a professional's total Qualification. A matrix of assessments can be applied to this methodology, in which the person in charge of evaluating can assign a relative importance of one dimension over another, or one competence over another.

$$
\% \text { Behaviour }_{i}: \frac{\sum \quad \text { Factor Scores }}{N^{\circ} \text { Factors } \times 5} \times 100 \text { (1) }
$$

\section{CONCLUSIONS}

The present research aims at taking a first step in the creation of a Lean competency management system in construction that allows the future development of behavioural 
indicators. With this purpose, it was possible to identify, through consultation with Latin American experts, the main dimensions or action areas that identify a project with a Lean approach in construction beyond the implementation of Last Planner System. Literature review and the subsequent validation and complement by Latin American professionals, who are in charge of managing these dimensions in their projects, allowed the creation of a set of competences related to them.

Regarding the updating of competences, it can be said that $85 \%$ of the competences retrieved from the literature were identified in the interviews through textual quotation, and although others were not literally evidenced in their words, they were acknowledged as present under the general discourse of the interviewees. In this way, the proposed model could be useful to identify and measure the skills that should be identified or developed in professionals in charge of implementing Lean in organizations that seek competitive advantages through this philosophy.

This study's future development lines will focus on the construction of an updated list of behaviours for the other Lean dimensions identified, as this research only covered the 3 main ones. A methodology must also be developed to statistically validate the graduation of behaviours using a representative sample, which only remains at a proposal level for the purposes of this research. Future results are expected to focus on the construction of Lean behaviour indicators in the Latin American construction industry, and the methodology should set a precedent for future regions.

\section{REFERENCES}

Alarcon, L., Salvatierra Garrido, J. L., Donaire, N., Galleguillos, M., Rodriguez, I., Lagos, C., and Herrera, R. F. (2017). Lean Construction: Manual Práctico de Herramientas de Mejoramiento de Construcción (Lean Construction: A Practical Manual of Construction Improvement Tools), Santiago: Gepuc.

Alles, M. A. (2006). Selección por competencias (Selection by competences), Buenos Aires: Granica.

Bessant, J., Caffyn, S., and Gallagher, M. (2001). An Evolutionary Model of Continuous Improvement Behavior. Technovation, 21(2) 67-77.

Boyatzis, R. E. (1982). The Competent Manager: A Model for Effective Performance. New York: Wiley.

Erol, H., Dikmen, I., and Birgonul, M. (2017). Measuring the impact of lean construction practices on project duration and variability: A simulation-based study on residential buildings. Journal of Civil Engineering and Management. 23, pp. 241-251.

España, F., Tsao, C. C., and Hauser, M. (2012). Driving Continuous Improvement by Developing and Leveraging Lean Key Performance Indicators. 20th Annual Conference of the International Group for Lean Construction., pp. 18-20.

Fauchier, D. and Alves, T. C. (2013). Last Planner® System Is the Gateway to Lean Behaviors. 21th Annual Conference of the International Group for Lean Construction, pp. 559-568.

Pavez, I., and Alarcon, L. F. (2007). Lean Construction Professional's Profile (LCPP): Understanding the Competences of a Lean Construction Professional. 15th Annual Conference of the International Group for Lean Construction, pp. 453-464.

Pavez, I., and Alarcon, L. F. (2008). Lean Construction Professional's Profile (LCPP): Implementation in Chilean Contractor Organizations. 16th Annual Conference of the International Group for Lean Construction, pp. 231-240. 
Picchi, F., and Granja, A. (2004). Construction sites: using lean principles to seek broader Implementations. Proceedings of International group of lean construction,12th annual conference, pp. 3-5.

Salunkhe, A. (2018). General overview of Lean Management in Construction Industry. International Research Journal of Engineering and Technology (IRJET) 05.07, 19992004.

Salvatierra, J. L., Funk, R., and Alarcón, L. F. (2016). Chilean Construction Industry: Workers' Competencies to Sustain Lean Implementations. 24th Annual Conference of the International Group for Lean Construction, pp. 20-22.

Zuo, J., and Zillante, G. (2005). Project Culture Within Construction Projects: A Literature Review. 13th Annual Conference of the International Group for Lean Construction, pp. 353-361. 